\title{
4 \\ THE ECONOMY: A Public Place For Private Activity
}

\begin{abstract}
Although it is generally true that pre-seventeenth century philosophers did not focus on economic questions, they were not, as has been suggested, disinterested in them. ${ }^{1}$ One finds, in Aristotle in particular, not only his commonly known argument that an individual cannot live virtuously without property, but the parallel one that a city needs property too. One finds, not only these arguments, but the concept of a public economy. Aristotle is unlike some modern political thinkers in that his economic proposals do not provide the key to his philosophy and thus to his views on the public and the private, but they do help to illuminate those views.

Before proceeding to the interpretive debate, we should address a not insignificant methodological controversy: what material in the Aristotelian corpus is legitimate and relevant to Aristotle's economic views? First of all, to stress, as M. I. Finley does, that Aristotle "wrote no Economics" is misleading. ${ }^{2}$ As noted in Chapter 2, the first book of the Oeconomica includes Aristotle's own writing, and the remainder of the work draws on his thinking. Further, two of the three books of the Oeconomica pertain to economic matters; the first book on household management is useful especially in conjunction with Book I of the Politics, and the second book, although comprising largely anecdotes, directly concerns public economy-
\end{abstract}

1 See Robert L. Heilbroner, The Worldly Philosophers: The Lives, Times, and Ideas of Great Economic Thinkers, 4th ed. (New York: Simon and Schuster, 1972), 36.

2 The Ancient Economy, 2d ed. (Berkeley: University of California Press, 1985), 21. 
the ways rulers collect taxes and manage a city's economic affairs. ${ }^{3}$ As to the possible objection that oikonomia means household management, one must note, as Finley admits, that Aristotle could be using the word to mean public administration (Pol 1299a20-23, 1308b32; Oec 1345b7-1346a25). ${ }^{4}$ Second, although Finley and others indicate that only Book V of the Nicomachean Ethics and Book I of the Politics should form the basis for a discussion of Aristotle's economic views, one finds throughout the Politics, not systematic treatments of economic questions, but passages that complete his conception of an economy. ${ }^{5}$ One must be mindful, though, of his placement of economic proposals-whether in the books about ordinary regimes or in those about the ideal regime.

\section{RIVAL INTERPRETATIONS}

There are at least six overlapping interpretations of Aristotle's understanding of economics. One that has been shown in previous chapters to permeate Arendt's and feminist accounts of Aristotle holds that he understands economics to mean the business of 'fulfilling needs in the household: "According to ancient thought . . . the very term 'political economy' would have been a contradiction in terms: whatever was 'economic,' related to the life of the individual and the survival of the species, was a non-political, household affair by definition." 6 An economy may be defined as "an instituted process of interaction between man and his environment, which results in a continuous supply of want-satisfying material means."7 As earlier chapters have revealed, there is no doubt

3 In addition to the text itself, see G. Cyril Armstrong's "Introduction" to Aristotle: Oeconomica (Loeb Classical Library, 1935), 323-25.

4 Finley, "Aristotle and Economic Analysis," in Ethics and Politics, vol. 2, Articles on Aristotle, ed. Jonathan Barnes, Malcolm Schofield, and Richard Sorabji (London: Gerald Duckworth, 1977), 150 n. 32; see also Finley, Ancient Economy, 20.

5 Finley, "Aristotle and Economic Analysis," 142; Joseph A. Schumpeter, History of Economic Analysis, ed. Elizabeth Boody Schumpeter (New York: Oxford University Press, 1954), 60.

6 Hannah Arendt, The Human Condition (Chicago: University of Chicago Press, 1958), 29; Ernest Barker makes the same point in The Political Thought of Plato and Aristotle (New York: Dover, 1959), 357, but contradicts it in his translation of The Politics of Aristotle (Oxford: Clarendon, 1946), 22 n. E.

7 Karl Polanyi, "The Economy as Instituted Process," in Primitive, Archaic, and Modern Economies: Essays of Karl Polanyi, ed. George Dalton (Boston: Beacon, 1968), 145. 
that Aristotle establishes the importance of and explains how to institute this process in the household; but he also indicates the importance of establishing such a process in the city when he declares at the beginning of the Politics that the raison d'être of cities is self-sufficiency (1252b27-1253a1). Indeed, since Aristotle contends that both the household and the city aim to achieve selfsufficiency (the self-sufficiency that is possible for each) ( $\mathrm{Pol}$ 1261b11-12, 1280b33-35, 40-1281a1), it would be odd for him to offer only a theory of domestic economy.

According to Ernest Barker and Eric A. Havelock, Aristotle understands economics in terms of moral relationships between human beings and to concern only indirectly (primarily through the master-slave relationship) the meeting of physical needs and wants. Havelock, however, departs from Barker (giving us a third interpretation), by arguing that Aristotle extends economics beyond the family to include "the regulation of moral and authoritarian relationships between persons"; "in the larger area of the state, economy is another name for politics." 8 On the one hand, then, it might be said that Havelock, unlike Arendt and Barker, sees that Aristotle has some kind of concept of public economy. On the other hand, given that Havelock's Aristotelian economy is a function of human goodness and not of the condition of scarcity, it is clearly not Havelock's intention to suggest that there is agreement between Aristotle and modern economists about the origin of economy. ${ }^{9}$

M. I. Finley, Robert L. Heilbroner, and Joseph A. Schumpeter argue that, although one finds in Aristotle's works commonsense descriptions of economic activities, one does not find either economic analysis or a concept of economy. They argue that Aristotle did not have a concept of public economy because the ancients did not abstract the elements of production. Without the "impersonal, dehumanized" conceptions of "land, labor, and capital," "the laws of supply and demand," "cost" and "value," they could not conceive "the market system." "Of course," Finley explains, "they farmed, traded, manufactured, mined, taxed, coined, deposited and loaned money, made profits or failed in their enterprises. And

8 Havelock, The Liberal Temper in Greek Politics (London: Camelot, 1957), 343-44, 354. Barker, Political Thought, 357-59; for his supporting arguments, see 359-400.

${ }^{9}$ Havelock argues that Aristotle rejects all liberal ideas, including that of a societas cupiditatis-a political association aiming to satisfy private wants (Liberal Temper, 295-375). 
they discussed these activities in their talk and their writing. What they did not do, however, was to combine these particular activities conceptually into a unit, in Parsonian terms into 'a differentiated sub-system of society'."10

Finley does not merely rely on this intellectual explanation; he also emphasizes that the ancients lacked a concept of economy because their division of the population, into money-handling, noncitizen "metics" on the one hand and land-owning citizens on the other, prevented the possibility of investing in land and manufacture. "Greek conditions of choice" precluded the ancients from envisioning an "investment model." It was because their economy was confined to producing, trading, and money-lending that they did not conceive a market system. ${ }^{11}$

According to Finley, Heilbroner, and Schumpeter, then, the question of whether Aristotle had a concept of public economy is necessarily over whether he conceived a capitalist system. ${ }^{12}$ Karl Polanyi maintains that Aristotle presents a nonmarket, "sociological," concept of public economy-a "substantive" rather than a "formal" definition. ${ }^{13}$ Polanyi essentially agrees with Finley that Aristotle could not have arrived at the concept of a "disembedded" economy because market mechanisms during his time were at most embryonic; economic functions were still largely "embedded" in noneconomic institutions and customs. ${ }^{14}$ Nonetheless, living amid economic developments, Aristotle had the empirical basis for developing a concept of economy that was more than a concept of political or moral relations, as Havelock contends. According to Polanyi, Aristotle detected an economic dimension of human experience but found it expressed through "community, self-sufficiency, and justice"; in Aristotle's view, neither the fact of scarcity nor

10 Finley, Ancient Economy, 21; see also 22, 182, and "Aristotle and Economic Analysis," 146-56; Heilbroner, Worldly Philosophers, 17-27, 36; Schumpeter, History of Economic Analysis, 9, 53-65; but see note 19 below.

11 Finley, "Aristotle and Economic Analysis," 156-57; see also Heilbroner, Worldly Philosophers, 26.

12 See especially Finley, Ancient Economy, 22-23. This point is implied by Schumpeter's account (History of Economic Analysis, especially 58).

13 For Polanyi's discussion of the distinction, see "The Economy as Instituted Process," 139-48.

14 "Aristotle Discovers the Economy," in Primitive, Archaic, and Modern Economies, ed. Dalton, especially 80-82, 84-86, 111; see also Heilbroner, Worldly Philosophers, 17-18, and Havelock, who, although he does not give a historical explanation, finds in Aristotle's texts a fundamental duality between liberal economic theory and agrarianism overcome by the latter (Liberal Temper, 353-65). 
self-interest, but institutions or "the interests of the community," work to ensure the satisfaction of needs. ${ }^{15}$ The economy arises out of and depends on the community; the community is logically prior to the economy.

Cornelius Castoriadis also argues that Aristotle conceives the economy as wholly conventional. He admits that Aristotle says that need is the source of economies, since it is an available measure of value, and he also admits that Aristotle regards individuals as the necessary judges of their needs. But Castoriadis contends (as Polanyi hints ${ }^{16}$ ) that Aristotle thinks paideia-the institutions of a regime-determines or creates needs. Nomos conditions human beings. Moreover, man is convention's creature because, according to Aristotle, his physis/telos compels him to make himself: man is not ontologically determined. Thus, there is no ontological ground of the city-of nomos. To be sure, according to Aristotle human beings must bring about their own virtue, or make themselves. But it is equally clear that nature supplies them with directives, or the ontological basis for virtue. In fact, Aristotle denies that "everything just is merely conventional" and claims that "only one form of government is by nature the best everywhere" (NE 1134b24-25, 1135a5). Contrary to Castoriadis's suggestion, the fact that man is a political animal does not override or make clear the meaning of his naturalness. ${ }^{17}$ Men may only change natural justice and their natural appetites (NE 1134b18-1135a5, Pol 1253a31-37).

In other words, as Polanyi and Castoriadis indicate, Aristotle indeed has a concept of public economy and finds self-judged needs to be the impetus for and self-sufficiency to be the end of an economy. But in Aristotle's view, education or law cannot change the fact that nature manufactures needs and makes them felt only and unmistakably by individuals. Accordingly, law must acknowledge low nature by providing means to satisfy needs and by merely guiding rather than trying to supplant individual judgment. Indeed, Aristotle's fundamental observation that a whole cannot be sound unless its parts are supports the claim that the economy serves the whole by way of serving individuals.

In this chapter, I aim to show not only that Aristotle has a con-

15 “Aristotle Discovers the Economy," 96-100, 107.

16 Ibid., 99.

17 Cornelius Castoriadis, "From Marx to Aristotle, from Aristotle to Us," Social Research 45, no. 4 (1978), 713-15, 725-35. 
cept of public economy but that it presents economic concepts that resemble modern ones. To borrow Polanyi's distinction, Aristotle's description of an ideal empirical economy, his substantive concept of economy, suggests elements of a formal concept of economy. My objective in this chapter is to identify the economic concepts that inform Aristotle's institutional vision of economy. It should become clear that Aristotle is not so much uncritically compounding the two meanings of "economic" as trying to develop the conceptual apparatus to account for and explain the features of a market economy. To support this thesis, however, I need not show that Aristotle abstracts land, labor, and capital, for there are other concepts of a market economy-self-love as the economy's animus and subsistence as its end, for example, but also division of labor, private property, distribution, freedom of trade, competition, currency, value, monopoly, population growth, and even natural justice. ${ }^{18}$ Aristotle's use of some of these concepts-for example, those of money and private property-might appear in Schumpeter's terms as nothing more or not much more than commonsense requirements or fundamental facts of a market; not bearing or suggesting any superstructures, they cannot be said to embody discoveries and could be said to be commonplace. ${ }^{19}$ But they still convey important insights: Aristotle's justification of private property presupposes the notion of incentive, and he distinguishes currency from capital.

It is not, in any case, mostly the degree of sophistication of Aristotle's concepts-some of which are and some of which are not more than commonsense definitions - that holds together the thesis that he not only describes but conceptualizes or analyzes market economy; it is rather that his treatment of these concepts re-

18 These are some of Adam Smith's cardinal concepts, as summarized by D. P. O'Brien, The Classical Economists (Oxford: Clarendon, 1975), 30-36. Because Smith's ideas more than those of anyone else dominate classical economics, they are the basis for the notion of classical economics referred to in this chapter.

19 Schumpeter, History of Economic Analysis, 9, 54. Schumpeter himself says that Aristotle's contribution to economics is pedestrian and commonsensical (only) from the contemporary standpoint and grants Aristotle at least "an analytic intention" with respect to "matters touching value, price, and money" (57, 64; see also 60-63). By "economic analysis" Schumpeter means "the intellectual efforts that men have made in order to understand economic phenomena or, which comes to the same thing, ... the analytic or scientific aspects of economic thought" (3). 
veals an appreciation of their connectedness. ${ }^{20}$ His discussion of economic matters in both theoretical and practical terms suggests that he would be sympathetic to the later, modern displacement or disembedding of economics. That he witnessed economic activity becoming divorced, however tentatively, from traditional practices may have facilitated his attempt to express economic relations in conceptual terms, an attempt the impetus for which was his not finding such relations embedded in all human relationships. In any case, he tries to show that economics is not a dimension of all human experience by showing that it is a compartment of that experience.

\section{Aristotle and Classical Economics}

Among the fundamental ideas that are common to Aristotle and modern, especially classical, economics is that of natural law. As D. P. O'Brien explains, Adam Smith was influenced by four basic propositions common to any natural-law system: "that there is an underlying order in material phenomena; that this underlying order is discoverable either by reasoning from observed phenomena or from innate moral sense; that discovery of the underlying order leads to the formulation of natural laws which, if followed, lead to the best possible situation; and that positive legislation should reflect these natural laws."21 It would appear that Smith's belief that natural right rests not on reason but on the mechanism of sentiment does not separate him from Aristotle as much as one might think ${ }^{22}$ - a thought to which I have occasion to return.

20 Polanyi and I agree on the conceptual unity of Aristotle's economic ideas. He writes: "We have . . . every reason to seek in his works for far more massive and significant formulations on economic matters than Aristotle has been credited with in the past. In fact, the disjecta membra of the Ethics and Politics convey a monumental unity of thought. Whenever Aristotle touched on a question of the economy he aimed at developing its relationship to society as a whole" ("Aristotle Discovers the Economy," 95-96).

21 Classical Economists, 22; see also 24-32.

22 See Joseph Cropsey, "Adam Smith," in History of Political Philosophy, 3d ed., ed. Leo Strauss and Joseph Cropsey (Chicago: University of Chicago Press, 1987), 639; O’Brien, Classical Economists, 31. 
Another point is worthy of note: mainstream classical economics "was in essence not a model building phenomenon." David Ricardo's Corn Model "was not a very serious detour" in the development of classical economics and "attracted hardly any disciples." 23 That Aristotle built no Ricardian models, then, does not mean that his economic concepts can have no affinity with classical economics.

It has, however, been indicated that a formal concept of economy tries to explain the logic of "a definite situation of choice" rather than to describe an "instituted process." 24 Thus, the claim that Aristotle presents elements of a logical concept of economy must be supported by evidence that he is trying to simplify reality, generalize relations, or present an ideal type. ${ }^{25}$ In fact, Aristotle makes several such attempts. For example, he does not describe agriculture and commerce, but he explains the concepts of natural and unnatural acquisition. He also presents the concept of selfsufficiency-an ideal that resembles Adam Smith's concept of the stationary state. The concepts of commensurability and of the just price simplify reality by revealing the logic of exchange. Aristotle's distinction between public administration and political rule is also part of his attempt to clarify or conceptualize things economic. He may not have conceived all the logical constructs necessary to complete an economic model or system, but in conceiving a few building blocks, and in suspecting others, he appreciated some of the ideas classical economics later systematized.

The attempt to ally Aristotle's political philosophy with classical economics still might appear misguided, since his portrait of the best regime promotes a fundamentally agrarian economy supported by public and private farmers (Pol 1278a11-13, 1330a9-13, 25-31). Fundamental agrarianism is not, however, pure agrarianism; self-sufficiency cannot be achieved, Aristotle teaches, without a profit-generating market. Furthermore, one must always bear

23 O'Brien, Classical Economists, 43.

24 Polanyi, "The Economy as Instituted Process," 140, 145.

25 See Finley, Ancient Economy, 182, which cites Max Weber. It should be noted, however, that in practice, even under a market system, the formal and substantive meanings of economic of course coincide, and that not even Weber, Parsons, Marshall, or Durkheim disentangled the two meanings (Polanyi, "The Economy as Instituted Process," 141). Aristotle may not have disentangled the two meanings any more than he did, not so much because he lacked empirical or intellectual resources, but because, as he declares, it is crude to spend much time discussing economic matters (Pol 1258b35). 
in mind that Aristotle proposes both ideal and second-best measures. Agrarianism can be expected to prevail only among a certain sort of populace. Where virtue is not the norm, legislators should expect that money-making will attract most men; accordingly, if they are concerned to preserve the regime, they should legislate only to discourage, not to prohibit, money-making among citizens.

One might point out, however, that this sketch of the secondbest economy nonetheless rejects the "invisible hand" theory and natural liberty doctrine that together are the essence of classical economics, a fact not hitherto observed. But two other observations are relevant here. First, Smith's harmony theory presupposes the desirability of order or reason. Second,

liberty continued to mean for Smith what it had meant to Locke, to Aristotle, and to the long tradition of political philosophy: the condition of men under lawful governors who respect the persons and property of the governed, the latter having to consent to the arrangement in one way or another. ... [The capitalist project] is animated by a search for methods of institutionally liberating every man's natural instinct of self-preservation in the interest of external, politically intelligible freedom and peaceful prosperous life for mankind as a whole. 26

Thus, Aristotle's second-best regime and Smith's best seem to intersect. $^{27}$

\section{THE BEST ECONOMY}

We should now consider evidence for the claim that Aristotle has a concept of public economy that both reveals an appreciation of some of the concepts of classical economics and highlights the failings of liberal economic theory and the dangers of a liberal economy.

26 Cropsey, "Adam Smith," 652. See also Cropsey, Polity and Economy: An Interpretation of the Principles of Adam Smith (The Hague: Martinus Nijhoff, 1957), 24; O'Brien, Classical Economists, 32.

27 For the claim that the first five chapters of Adam Smith's Wealth of Nations develop Aristotle's thoughts on economics, see Schumpeter, History of Economic Analysis, 60, 63. 


\section{The Division of Labor and Productivity}

One fundamental concept Aristotle and classical economics share is the division of labor. ${ }^{28} \mathrm{He}$ recommends, not only that private slaves mainly provide services and public slaves mainly produce goods, but that different slaves among each group assume different tasks. For example, some public slaves should produce food, some artifacts; still others should transact business. Among those producing artifacts, some should make shoes and some, houses. Among those transacting business, some should transact domestic and others foreign business (Pol 1261a22-37, 1327b11-13, 1328b5-7, 20-21, 1329a35-37, 1331a32-35, b1-4). To surmise that Aristotle might have conceived and found appropriate further divisions of labor may not be unreasonable, but it is not necessary in order to show his recognition of the basic idea. ${ }^{29}$ Still, Aristotle would almost certainly recommend that labor cease being divided before it becomes so injurious to the body as to make laborers useless (Pol 1337b12-14).

But is the rationale for such a division the one classical economics gives-namely, productivity? Aristotle indicates that it is indeed one rationale: a city cannot be excellent without its citizens being excellent, and they cannot be excellent if they are in want of sustenance and possessions (Pol 1332a32-34, 1329a17-19, 1330a2). The good life presupposes self-sufficiency (Pol 1252b27-1253a1, $1321 b 17-18)$. One might object, however, that self-sufficiency is not growth, which requires the production of surplus and investment, or capital. ${ }^{30}$ On the one hand, this observation indeed seems to signal a crucial difference between Aristotelian and classical economics. Aristotle praises acquiring wealth "naturally" by agricultural means and bartering because such activities are limited: they arise from needs and end with the satisfaction of those needs.

28 Schumpeter acknowledges that this is part of Aristotle's bequest to economic theory but denies that the knowledge that the division of labor increases productivity embodies a scientific discovery (History of Economic Analysis, 9, 60). My claim is not that it is such a discovery, only that division of labor is one of Aristotle's many concepts that together begin to resemble the concept of a market system.

29 According to Adam Smith, the extent of division of labor is a function of the capital stock available to support it. Furthermore, Smith admits that division of labor in the agricultural sector-the sector that according to Aristotle should predominate-is necessarily limited by the seasonality of many tasks ( $\mathrm{O}^{\prime}$ Brien, Classical Economists, 209).

30 Ibid., 34. 
And he seems to denounce money-making precisely because it allows and encourages the production of (unnecessary) surplus or profit (Pol 1257a6-1258b33, Oec 1343a26-30). On the other hand, he also indicates that both individuals and cities should have more than necessities. "Self-sufficiency is having everything available and being in need of nothing" - but in need of nothing for living "at leisure in liberal fashion"; self-sufficiency is the mean between penury and luxury (Pol 1326b29-31, 36-39). One cannot be generous without having things to give away or loan; one cannot exercise moderation if one feels always in need (Pol 1263b11-14; NE 1120a5-6, 24-26, 34-b2, 1119a16-18, b15-17). ${ }^{31}$ In fact, Aristotle lists wealth (ploutos), goods or money (chrēmata), 32 and profit (kerdos) among the pleasant things that, though they "admit of excess," "are worthy of choice in themselves" (NE 1147b23-25, 29$30,1148 \mathrm{a} 22-28, \mathrm{~b} 2-5)$. Citizens should also have money to pay taxes (Pol 1283a17-19). A city too needs surplus. It needs surplus goods to trade for goods it cannot itself produce ( $\mathrm{Pol} 1327 \mathrm{a} 25-27){ }^{33}$ In addition to surplus goods, a city needs "a certain abundance of money [chrēmatōn tina euporian]" to finance an army, a navy, and domestic projects and functions (Pol 1328b10-11, 1267a20-21, 1327a21-23; Oec 1345b19-27). In short, a city should accumulate wealth as long as it is intended for future use (Pol 1327a25-31, 1328a33-35, 1267a21-24, 1256b36-37), a view consistent with the spirit of the classical economic notion of investment. ${ }^{34}$

31 Thus, the concept of "property as a right of disposing of definite objects" was not foreign to Aristotle, as Polanyi implies ("Aristotle Discovers the Economy," 90).

32 Chrêmata "is an ambiguous word, often meaning money and always suggestive of it"; see The Politics of Aristotle, vol. 2, ed. W. L. Newman (New York: Arno Press, 1973), 187, note on $1257 \mathrm{~b} 7$.

33 "In order to procure supplies, it is imperative that a city should be able to import commodities which it does not itself produce, and to export, in return, the surplus of its own products" (Pol 1327a25-27). Regarding trade as a means to selfsufficiency, Aristotle is not, as Finley says, conceding that self-sufficiency is not in fact possible (Ancient Economy, 125). And contrary to Polanyi's claim ("Aristotle Discovers the Economy," 94, 98-99), Aristotle does have an economic concept of scarcity. Nature is niggardly from the point of view of civilization, and natural slaves cannot alone redress the condition of scarcity.

34 As noted earlier, Aristotle's description of a self-sufficient regime calls to mind Adam Smith's description of a "stationary state": a state that "has attained its 'full complement of riches,' which full complement is a function of the nation's laws and institutions, and its soil, climate, and geographical situation" (Cropsey, Polity and Economy, 75-76; see also O'Brien, Classical Economists, 210-11). Smith divided surplus, which he called "stock," into three categories: "that for the immediate consumption of the holders of stock (food, clothes, housing, and furniture); circulating 
Where Aristotle's notion of division of labor differs from the modern one is in not presupposing prosperity as its main rationale. Its main rationale is the diversity or inequality of individuals; nature makes each being to suit a purpose (Pol 1252b1-2, 1256b2021). The fortunate consequence is not merely self-sufficiency but quality products (Pol 1261a35-39), and not only these but the edification rather than the stultification of all workers (Pol 1255a1-2, b12-13, 1278b32-36). The latter is the inevitable consequence of assuming equality when dividing labor, a consequence of liberal capitalism which Adam Smith hinted was on the order of a moral irregularity ${ }^{35}$ and which Karl Marx declared to be much worse.

\section{Distribution}

If both citizens and cities need wealth, then how should they acquire it? According to Aristotle, a regime's territory should ideally be large enough and its population small enough so that each household may own two tracts of land (one near the city, the other near the border) from which household members can live liberally but moderately (Pol 1330a14-16, 1326b30-32). ${ }^{36}$ Private domestic and field hands provide necessary labor (1330a25-31). Farming,

capital (. . . money, stocks of provisions, raw materials, stocks of finished goods); and fixed capital (machinery, productive buildings, land improvements, and useful or acquired abilities). According to Smith, fixed capital was of no use without the cooperation of circulating capital and, writing at the beginning of the Industrial Revolution, he placed relatively little emphasis upon it. Capital formation was produced by directing stock into categories 2 and 3 . It was increased by parsimony and diminished by prodigality and misconduct" (O'Brien, Classical Economists, 207).

In Aristotle's view, to borrow Oakeshott's terms, economic players form not simply a transactional association but an enterprise association in that they share a substantive purpose-namely, the economic well-being of the city; this does not detract from the fact that they make decisions in response to continuously emergent situations and that therefore "these decisions are only contingently connected with the common purpose" (On Human Conduct, 114-15). Because, in a well-arranged regime, the marketing element in effect procures a substantive condition benefiting the whole, Aristotle can without contradiction denounce mere transactional association (Pol 1280b17-23, 29-31) while including a market in the best regime.

35 Cropsey, "Adam Smith," 647-51, and Polity and Economy, 77-79, 89-92; see also O'Brien, Classical Economists, 209-10.

36 On this interpretation of Pol 1326b30-32, see Aristotle: The Politics, trans. Carnes Lord (Chicago: University of Chicago Press, 1984), 266 n. 15. Eric Roll observes that the notion of incentive informs Aristotle's arguments for private property: people care for their own property more than communal property ( $P o l$ 1261b33-35, $1262 \mathrm{~b} 22-23,1263 \mathrm{a} 27-29)$ and are less likely to quarrel about property if it is distributed according to merit or industry (Pol 1267a39-41); see A History of Economic Thought, 4th ed. rev. (Homewood, Ill.: Richard D. Irwin, 1974), 31. As Schumpeter remarks, Aristotle's arguments for private property "read almost exactly like the arguments of middle-class liberals of the nineteenth century" (History of Economic Analysis, 59). 
raising livestock, and raising other animals are the three "most proper" forms of livelihood because, productive only of limited things, they do not exacerbate acquisitiveness; they are the "most just" forms because they do not derive wealth from human beings (Pol 1257b33-1258a1, b1-2, 12-20; Oec 1343a28-29). Aristotle evidently agrees with Xenophon's Socrates that "[farming] seems to turn out the best citizens." 37

But, as we know and as Aristotle has observed, a household is not as self-sufficient as a city (Pol 1261b11-12). Households may need the produce of other households; thus Aristotle says that citizens should share their private property (Pol 1329b41-1330a2). Sharing property is better than buying or selling it because it is a sign of and cultivates generosity, which is more noble than selfinterest (Pol 1263a30-39, 1270a19-21; NE 1120b27-1121a7). But households also need their own artifacts and equipment-shoes, pots, harnesses - items citizens cannot expect their slaves to make because of their lack of expertise and their duties. Thus, need gives rise to a class of artisans (Pol 1291a1-2, 1328b6, 21) and a means for citizens to acquire their wares - that is, a market (Pol 1321b14-17, 1331b1-2). ${ }^{38}$ This market should not apparently be restricted to barter and trade, as Barker and Ross imply, but should be open to commerce because, as noted earlier, a city needs taxpayers and other sources of revenue ( $\mathrm{Pol} 1283 \mathrm{a} 16-18,1259 \mathrm{a} 34-35 ;$ Oec II). ${ }^{39}$ In short, paradoxically, human beings need the unnecessary sort of expertise in business ( $\mathrm{Pol} 1258 \mathrm{a} 14-16){ }^{40}$ The need for commerce in

37 Oeconomicus, trans. E. C. Marchant (Loeb Classical Library, 1923), 411-12.

38 Such a class would be constituted of those who have more virtue than slaves but less virtue than citizens ( $\mathrm{Pol} 1260 \mathrm{a} 36-\mathrm{b} 2)$. Aristotle does not give a clear account of the virtues of the artisans as a human being; see Aristotle: Politics, trans. H. Rackham (Loeb Classical Library, 1932), 64 n. c. On the ambiguity, see Politics, vol. 2, ed. Newman, 222, note on 1260b1; for a different interpretation, see Politics, trans. Barker, $37 \mathrm{n}$. 2. Perhaps this only testifies to Aristotle's seeing not so much classes as gradations of virtue among human beings (see Chapter 2).

39 Barker, Political Thought, 373-90, especially 375, 377, 389, 390; W. D. Ross, Aristotle: A Complete Exposition of His Works and Thought (New York: Meridian, 1959), 236.

40 Roll observes that Aristotle's condemnation of usury is meant to set the ethical limits of commerce (History of Economic Thought, 33): it is wrong to accumulate money by selling money for the sake of accumulating money, but fine to accumulate money by selling goods for the sake of procuring other goods and services. It should be noted, however, that "Aristotle's long discussion of the two arts of money-making was not just an attempt to drive home an ethical distinction. . . . For the first time in the history of economic thought the dichotomy of money and real capital ... is stated; but later economists stripped it of its ethical garb" (ibid., 33; see also 34, 35, and Schumpeter, History of Economic Analysis, 62). 
all regimes, even in the best, accounts in part for Aristotle's inclusion of "an excursus on liberal economic theory" in his defense of agrarianism in Book I of the Politics (chaps. 8-11). The other reason for the excursus, which Havelock cites as the only reason, is Aristotle's desire to dethrone liberal economics. ${ }^{41}$

\section{The Nature and Effect of Money-Making}

Aristotle disagrees with the liberal view that, as Michael Oakeshott puts it, "productive enterprise" is "itself, internally, a want-satisfying activity." 42 Money-making intensifies rather than satisfies desire. It tends to become obsessive because money, unlike goods, can be accumulated without limit; it does not spoil or take up space, and the supply is limited virtually by how much others are willing to exchange ( $\mathrm{Pol}$ I.9). Free enterprise does not yield freedom. ${ }^{43}$ In fact, it can generate conflict: when men see others making a profit, they become angry out of envy or due to the perception that it "involves taking from others" (Pol 1258b1-2, 1302a38-b2). Finally, because money has only relative not absolute value (Pol 1257b10-14), its use habituates men to judge relatively. It is, then, the having rather than the acquiring of a certain amount of money that is pleasant and choiceworthy; having money fulfills the need to know that tomorrow's needs can be fulfilled easily (NE 1133b10-13)-knowledge that allows engagement in liberal pursuits today. ${ }^{4}$

Since a life focused on money discourages virtue, citizens should not engage in business (Pol 1328b39-41). Moreover, a regime cannot afford to lose its citizens-its soldiers, rulers, fathers, philosophers, and priests-to obsessive and incendiary pursuits. Since

41 Havelock, Liberal Temper, 353-65.

42 On Human Conduct, 293-94.

43 See also William J. Booth, "Politics and the Household: A Commentary on Aristotle's Politics Book One," History of Political Thought 2, no. 2 (1981), 221, 223; Leo Strauss, The City and Man (Chicago: University of Chicago, 1964), 33.

44 To appreciate Aristotle's point more precisely, one should also note that he is critical not of producing or making but of acquiring. He seems to rank action (praxis) above production (poiesis) when he says that "life is action not production" (Pol 1254a7) - apparently because production is not activity for its own sake (NE 1140b67); see Politics, trans. Barker, $10 \mathrm{n}$. 2. Nonetheless, he includes in the category of poiessis the making of an argument, a speech, and a poem-products he deems, in the Topics, Rhetoric, Poetics, and Metaphysics, important to living well; see John Herman Randall, Jr., Aristotle (New York: Columbia University Press, 1960), 272; Arendt, Human Condition, 301. In short, Aristotle appears hostile only to the 'homo faber mentality' central to classical economics, insofar as classical economics has corrupted poiēsis (see Arendt, Human Condition, 304, 306). 
Aristotle recognizes the need for a market and merchants even in the best regime, we must therefore conclude that he thinks that noncitizens should transact business. ${ }^{45} \mathrm{He}$ would seem then to be recommending the sort of arrangement that existed during his time, according to which only outsiders-transient and resident aliens-carried out business; he might also agree with Xenophon, who, in a pamphlet on revenues, notes that metics are one of the best sources of revenue since they pay taxes and are not paid by the state. ${ }^{46}$ Yet Aristotle notes two dangers of admitting "the seafaring mass" to the polis: overpopulation resulting in poverty, which in turn leads to unrest and crime (Pol 1265b6-12, 1327b78), ${ }^{47}$ and democratization. ${ }^{48} \mathrm{He}$ reminds us that citizens are draftable and that, when the lowest class of citizens help to bring about a victory, the cause of democracy is strengthened because they thereafter have influence in the assembly (Pol 1304a17-24, AC 27.1). ${ }^{49}$ It would be better, then, for public and private slaves-noncitizen members of the city (Pol 1326a16-21, b20-22), not immigrants-to transact business for citizens. Apparently, the main acquiring a free male householder should do is that of acquiring servants.

\section{The Just Price versus the Natural Price}

What principle should govern the allocation of goods within the market? Aristotle indicates that the principle of distributive justice is proportionate equality: "As builder is to shoemaker, so must the number of shoes be to a house" (NE 1133a22-23) - but what exactly does this mean? A compelling interpretation, which both Finley and Polanyi put forth, is that the producer's standing in or worth to the community ought to determine the value and so the price of his products. ${ }^{50}$ Thus, not only should the builder's house command

45 In a significant but unelaborated departure from his thesis that Aristotle has only an embedded concept of economy, one in which community, not gain, is the object, Polanyi states: "If exceptionally gainful retailing there must be for the sake of a convenient distribution of goods in the market-place, let it be done by noncitizens" ("Aristotle Discovers the Economy," 97).

46 See Finley, "Aristotle and Economic Analysis," 156-58, and Ancient Economy, $65,70-79,162-64$.

47 As is well known, T. R. Malthus made the study of the economic ramifications of population size part of classical economics (O'Brien, Classical Economists, 56-66).

48 Aristotle may be responding to Xenophon's proposal to allow metics to own residential property (see Finley, Ancient Economy, 163, and "Aristotle and Economic Analysis," 158).

49 See also Politics, trans. Barker, 213 n. 2, 378, and Politics, trans. Lord, 260 n. 27.

50 See Finley, "Aristotle and Economic Analysis," 142-48; Polanyi, "Aristotle Discovers the Economy," 97, 107-8. 
more than the shoemaker's pair of shoes, but builder Ariston's house might command more than builder Aischron's. Another possible meaning is that the skills of each producer, abstracted from the talent brought to those skills and from social status, should determine price. ${ }^{51}$ Thus, Ariston's and Aischron's houses should command the same price. According to Schumpeter, if this is Aristotle's meaning, then it appears that he "was groping for some labor-cost theory of price" or reaching for the notion of abstract labor as the basis for the commensurability of goods. But Schumpeter's speculative interpretation contravenes the spirit if not the letter of proportionate equality. ${ }^{52}$ It seems that Aristotle indeed thinks that the worth of the producer should determine the price of his products; but it is important to say, as Finley and Polanyi do not, that Aristotle maintains that a community ought to base the worth of a producer and thus of his goods or servicesnot on his family name, wealth, or the fact that he is a human being-but on his talent or expertise and, insofar as these presuppose integrity or other moral qualities, his moral virtue ( $N E$ 1131a24-29). Put differently, because the caliber of a good or service reflects the excellence (or lack thereof) of the producer-who chooses what to produce (a cure, a lecture, a table) and is responsible for its quality (a fradulent cure, an organized lecture, a sturdy table) - the producer's excellence merits reward.

Aristotle means then that 'as builder $X$ 's excellence is to shoemaker $Y$ 's, so must the number of $Y$ 's shoes be to $X$ 's house.' Prices among houses and shoes should vary considerably; a pair of Mr. Reliable's durable shoes should command more than Mr. Cheapskate's shack. Likewise, not all products or services of a kind

51 The view of Schumpeter, Spengler, and Soudek as reported by Finley, "Aristotle and Economic Analysis," 146.

52 Schumpeter, History of Economic Analysis, 60-61 n. 1. Aristotle would no more think of the builder's labor as simply a multiple of the shoemaker's than he would think of the man's courage as simply a multiple of the woman's, or of the woman's intellect a multiple of the slave's. This is not because, as Marx explains and Finley agrees, Aristotle was blinded by his culture's prejudices and practices from seeing the homogeneity of human labor; it is the result rather of Aristotle's observing and reflecting on the differences among human beings and their achievements or products; see Finley, "Aristotle and Economic Analysis," 148; Harvey C. Mansfield, Jr., "Marx on Aristotle: Freedom, Money, and Politics," Review of Metaphysics 34, no. 2 (1980), 355-57, 363, 367. As Finley points out, Schumpeter's hypothesis is also rendered doubtful by the fact that "Aristotle does not once refer to labour costs or costs of production" ("Aristotle and Economic Analysis," 146; see also Ancient Economy, 81). 
should command the same price: as author $P$ is to author $Q$, so the price of author $P$ 's book should be to that of author $Q$ 's book; likewise, professor $A^{\prime}$ 's classes should command higher fees than professor F's; at the same time, perhaps carpenter Sam's services should command higher fees than professor $F$ 's.

But Aristotle also identifies need as the basis of price: money is merely "the exchangeable representation of need" (NE 1133a2629). Different things cannot in fact become commensurate-an apple, a trinket, and a book seem to have different values apart from circumstances-but, for practical purposes, "they can become commensurate enough in relation to our needs" (1133b19-20)..$^{53}$ On this account, price is necessarily determined by the buyer's estimate of his need and of the capacity of an item or service to fulfill it, and by the seller's estimate of his need(s) and of the capacity of an amount of money (its purchasing power) to fulfill them.

These two accounts of the just price are in one way compatible. Taken together, they indicate that price ought to reflect a judicious or true estimate of need; the price of an item or service ought to measure its contribution to virtue or noble living. Citizens ought to need the right products and services. Ideally, the market would be a place in which prudence and moderation were exercised and through which other virtues were facilitated: a preserve of private activity. But Aristotle is not, contrary to Polanyi's assertion, naive. This concept of the just price is an ideal, one that presumes that consumers consider their true or civilized needs. Demand should be a function of the requirements of virtue. ${ }^{54}$ Still, Aristotle realizes that wants do not always reflect virtue or the interests of the community but nonetheless do set prices (NE 1133b1-3). The bargained, or "natural," price must prevail. ${ }^{55}$

53 Even Marx credits Aristotle with the discovery of the commensurability of goods. But Marx argues that need cannot be the basis for commensurability because it is subjective or "partly arbitrary," whereas human labor is objective or "nonarbitrary." Aristotle would point out in response that only need could possibly render a toilet bowl commensurable with the most beautiful painting (see Mansfield, "Marx on Aristotle," 354-55, 360).

54 As Roll says, "in Aristotle we see the first separation and reunion of the positive and the ethical approach to the economic process. . . But the distinction between the forms which economic activity actually takes and the ethical precepts which should underlie it is clearly brought out" (History of Economic Thought, 35).

55 Put broadly, the best regime is possible because "no miraculous or nonmiraculous change in human nature is required for its actualization; it does not 
But Aristotle recognizes not only the intractability but the salutariness of self-interest or neediness, especially in economic matters. First of all, neediness, whether in its correct or perverse form, makes human beings willing to engage in exchange or reciprocate, and only exchange can bring about self-sufficiency (NE 1133b6-10, 1133a2; Pol 1321b14-18). By contrast, Polanyi argues that Aristotle thinks self-interest precludes reciprocity: "The bargained price might yield a profit to one of the parties at the expense of the other, and thus undermine the coherence of the community instead of underpinning it."56 Recall that Aristotle says commerce involves taking from others, but he also says "by their consent." This does not make commerce necessarily just, but it cannot be understood to have the power of undermining the community in the way that war does (Oec 1343a28-33). The unifying effect of self-interest tends to outweigh its divisive potential. Self-interest, by way of commerce, is salutary also in that it generates revenue for the city. Indeed, one wonders if behind Aristotle's recommendation to confine the market to one locale in the regime (Pol 1331b6-13) lies not only a concern for the virtue of the citizens but for the degree of competition in the market.

\section{The Role of Government: Agoranomoi and Treasurers}

As even Adam Smith observed, competition alone cannot optimize exchange. ${ }^{57}$ It is not then without reason that Aristotle dis-

require the abolition or extirpation of that evil or imperfection which is essential to man and to human life"; see Leo Strauss, Natural Right and History (Chicago: University of Chicago, 1953), 139; contrast Polanyi, "Aristotle Discovers the Economy," 107. Technically, according to Adam Smith, the natural price is the "right norm" of market prices (Cropsey, Polity and Economy, 72; O'Brien, Classical Economists, 79, 80, 82). Schumpeter also thinks that Aristotle is arguing that competitive prices are the standards of commutative justice, but he rejects the claim that Aristotle believes goods and services have inherent objective, "metaphysical" values (History of Economic Analysis, 61-62).

In addition, as Finley points out against Polanyi, Aristotle "knew perfectly well that prices sometimes responded to variations in supply and demand"; the relative value of currency and the supply-demand-price mechanism did not escape him (see Pol 1259a5-36, 1308a36-38; NE 1133b13-14, as cited by Finley, "Aristotle and Economic Analysis," 149; see also Roll, History of Economic Thought, 35). Schumpeter, who decries the early theory of supply and demand as close to common sense, nonetheless admits that it is scientific (History of Economic Analysis, 9).

56 "Aristotle Discovers the Economy," 108; see also 97, 110-11.

57 O’Brien, Classical Economists, 31-33; see also Cropsey, "Adam Smith," 651, 652, and "Political Morality and Liberalism," in Political Philosophy and the Issues of Politics (Chicago: University of Chicago Press, 1977), 138. On the role classical economics in general assigns to government, see O'Brien, Classical Economists, 272-77; Oakeshott, On Human Conduct, 294-95. 
cusses legal justice after he identifies want as the basis of exchange (NE V.6-7). In the Politics he recommends specifically that regimes establish the office of market manager (agoranomos) to make and enforce rules of fair practice (1321b12-14, 1299b16-17). Describing the Athenian arrangement, Aristotle writes:

Market magistrates . . . are required by the laws to take responsibility for all goods that are on sale, to ensure that what is sold is in good condition and genuine. . . measures magistrates . . . are responsible for all measures and weights, to ensure that the salesmen use honest standards. . . corn-wardens . . . are responsible for seeing, first, that the unground corn is sold honestly in the market, and then that the millers sell the meal in accordance with the price which they paid for the barley-corn, and that the breadsellers sell the loaves in accordance with the price which they paid for the wheat and that their loaves are of the prescribed weight. . . . port-superintendents . . . are bidden to take responsibility for trade and to compel the traders to convey to the city two thirds of the ... [incoming] corn. (AC 51)

Such regulation is necessary in the markets of all regimes ( $\mathrm{Pol}$ 1321b12, 1299b10-12), since not only slaves but also ordinary citizens are tempted to engage in corruption. But how regimes effect superintendence of the market may vary. A regime may decide to subsume the office of market manager under "a single office for orderliness" or charge a local board with overseeing the market (1299b14-20). Moreover, it may select agoranomoi in any of twelve ways (1300a30-31); the best way, however, is to appoint or elect from among persons with appropriate acumen or expertise $(1299 b 25,1300 b 4-5) .{ }^{58}$ By any means, there should be greater supervision of the best regime's market, both because it is easier to control slaves than free persons and because the best regime should of course meet higher standards of conduct in all areas (1299b27-30, 1300a4-8). ${ }^{59}$

Regimes should also establish the office of treasurer (tamias), to collect funds and allocate them to various government agencies

58 For a summary of the ways, see Politics, trans. Lord, 259 n. 58, and Harvey C. Mansfield, Jr., Taming the Prince: The Ambivalence of Modern Executive Power (New York: Free Press, 1989), 308 n. 27.

59 Thus, apparently, Aristotle thinks that obedient slaves might conduct themselves better in the market than might less supervised ordinary citizens. 
(Pol 1321b31-33). This office should tax most "the special products of the country"; at a rate only second to these, sales and services that are not "everyday transactions"; necessary goods and services should be taxed the least (Oec 1346a6-8). The tax office should also make sure that the regime's budget is balanced (Pol 1314b4-5, Oec 1348b23-30). This function is important enough that government may have to find innovative, even nobly deceitful, ways to collect funds, of which Book II of the Oeconomica provides dozens of examples. ${ }^{60}$

Every regime should have, then, at least these two exclusively "economic" offices (ai oikonomikai) (Pol 1299a23, 1259a35-36, 1256b36-37). These offices should not, however, carry with them the sort of power a general has (Pol 1300b9-12). Regimes should not have command economies; ${ }^{61}$ regulations should not be many or strict (Pol 1264a29-32);62 and government should tax only according to its current or anticipated needs. A well-managed city does not tax and spend unnecessarily (Pol 1314a40-b7). ${ }^{63}$ In fact, because economic offices should not be powerful, they should not, technically, be called offices (archas) (Pol 1299a20-28).

Why should economic administration exert less power than political rule? Because of the nature of economic activity and the needs of regimes. It would be futile to try to limit much what is by nature limitless; circumscribing free enterprise beyond a certain

60 For example, Mausolus, lord of Caria, told the people of Mylassa that their unfortified city was under threat of attack and solicited funds to build walls, but he kept the money without building them (Oec 1348a11-18).

61 During the Peloponnesian War, before an expedition, generals arranged to have local markets along a prospective route set up or prepared for the arrival of their troops; also, both armies and navies brought along civilian retailers, whose job it was to wait on the men and sometimes to sell booty locally (Polanyi, "Aristotle Discovers the Economy," 103-4, which cites Xenophon's Cyropaedia VI.ii.38f and the Aristotelian Oeconomica II.23a). Thus, military leaders literally commanded economies. Aristotle may be making (at Pol 1300b9-12) an oblique reference to this practice.

62 See Politics, vol. 4, ed. Newman, 268, note on 1300 b11.

63 Greek city-states normally levied taxes on an ad hoc basis, when they needed to finance a war or expedition, relieve famine, or the like. According to Finley, any form of direct uniform tax was considered tyrannical (Ancient Economy, 164, 175). The various temporary ways cities should raise revenue according to Aristotle may be found not only throughout Book II of the Oeconomica but in the Politics as well; for example, governments might establish temporary monopolies (1259a21-35). Aristotle thinks, however, contrary to the apparent practice of most ancient city-states, that government should act more prudently by always having sufficient funds to finance a war (Pol 1271b10-17, 1314b14-16). 
extent makes it unfree. Furthermore, it may be that unregulated interests tend toward order. Aristotle would remind us as well that regimes need funds; regulations should keep economic activity orderly and as ethical as possible, they should not repress a source of revenue.

In sum, according to Aristotle, government has the tricky task of both overseeing and reaping the necessary benefits of the economy. Laws must be conducive to the preservation of a regime, but at the same time the regime should not exist for the sake of transacting business ( $\mathrm{Pol} 1280 \mathrm{a} 31-38, \mathrm{~b} 17-35){ }^{64}$

\section{The SECOND-Best ECONOMY}

Regimes lacking ideal conditions-enough land for two tracts per household, a class of good men, and a class of natural inferiors to support them-must necessarily make more concessions to free enterprise. If there is not enough land and slaves for each citizen to live moderately, then some or all citizens must support themselves; wage labor and money-lending must complement agriculture and retailing as means of livelihood (Pol 1278a15-18, 1258b25, 1289b27$35,1290 \mathrm{~b} 38-1291 \mathrm{a} 6, \mathrm{~b} 18-20)$. This is the situation that exists in democracies and oligarchies (1290a13-16, 1291b11-16).

Furthermore, the marketing element has to be greater in number and more vigorous than in the best regime, for the city has a greater need for revenue. Like the best regime, ordinary regimes have to support a militia ( $\mathrm{Pol} 1291 \mathrm{a} 7-8, \mathrm{~b} 21)$ and provide common public services, but they also have to provide meals to their poor. The best regime too should provide common messes, but these should serve as political assemblies for the citizens (Pol 1330a3-8). How can ordinary regimes manage to feed their poor? Aristotle recommends the Cretan system: crops and animals for common meals are grown and raised on public land by farmers who rent the land for the privilege of keeping the surplus (Pol 1272a16-21). According to Aristotle, this form of welfare is the most just, for it ensures that the poor will not starve and yet does not enable them to live as they wish ( $\mathrm{Pol} \mathrm{1267b8-9);} \mathrm{further,} \mathrm{it} \mathrm{does} \mathrm{not} \mathrm{require} \mathrm{the}$ middle and upper classes to support them without return (NE

64 See also Strauss, City and Man, 32-33. 
1132b31-34). If, however, there is not sufficient public land to support the poor, then a regime must resort to something like the Spartan system, according to which all citizens are taxed a fixed amount, the penalty for noncompliance being the revocation of the privilege to participate in government ( $\mathrm{Pol} \mathrm{1272a13-15).}$

Ordinary regimes also need more funds than does the best to finance public service, as Aristotle records was the practice in democratic Athens ( $A C$ 24.3). A regime should fine the wealthy (who prefer to attend to their business; Oec 1352a5-9) for failing to serve and use the fines-and presumably other revenue-to pay others to serve; this ensures that all do their duty (Pol 1297a38-41). But Aristotle endorses the exclusively Athenian practice of paying citizens for a range of duties not only for political but also apparently for economic reasons. He seems to have attributed the health of the Athenian economy, indicated by a virtual absence of demands for debt cancellations and land redistribution, to the distribution of public funds, ${ }^{65}$ perhaps appreciating the general idea of supplyside economics? One suspects that he endorses pay for public service also because, unlike a welfare system, it effects reciprocity or justice.

Ordinary citizens can be counted on to generate through commerce the revenue needed for these public expenditures, for they desire lots of goods, luxuries, and profit, believing that an abundance of possessions and money brings happiness ( $\mathrm{Pol} \mathrm{1291a3-4,}$ 1318b16-17, 1257b8-9, 20-23, 33-1258a2). The public, then, should take advantage of private acquisitiveness. At the same time, no government should encourage baseness; government should allow commerce but not endorse it as a way of life. ${ }^{66}$ Accordingly, it should institute the best economic measures to the extent practicable: locate the market apart from the city and regulate it, prohibit officeholders from money-making, and encourage agrarian livelihoods (the latter it could achieve by taxing only or mostly manufactured goods rather than produce, and commercial rather than farm land). ${ }^{67}$

65 See Finley, Ancient Economy, 173.

66 See also Cropsey, "On the Relation of Political Science and Economics," in Political Philosophy, 39, and Abram N. Shulsky, "The 'Infrastructure' of Aristotle's Politics" (Ph.D. diss., University of Chicago, 1972), 226-27.

67 The rationale for encouraging agriculture in ordinary cities differs from the rationale for an agriculturally based economy in the best regime. In the latter, farming as a livelihood keeps citizens from producing and consuming too much; in 
A regime may in addition establish an upper limit on the amount of wealth any one citizen can accumulate-this being the greatest amount of wealth one can have without becoming so arrogant as to desire to rule continuously (Pol 1295b3-1296a2, 22-27). But if this limit is too low, the regime cannot benefit from the rich. Besides, any attempts to equalize property by law are ordinarily undone by common insatiable greed (Pol 1267a37-b5). Contrary to the claims of Phaleas and later of Marx, material conditions cannot alone eradicate or even substantially quell the limitless desire of human beings; citizens should receive education rather than equal property (Pol 1266a36-39, b28-31). Property matters per se should be left alone (Pol 1267b12-13).

It should be observed that the most acquisitive members of a society are the wealthiest only if they also have enough self-restraint (engkrateia) not to squander their acquisitions. The most virtuous, such as the citizens of the best regime, do not have to be constantly mindful of their consumption, for intellectual engagement displaces or transforms desire; the temperate man (ho sōphrōn) has no need for will (NE 1146a9-12, 1104b5-6). ${ }^{68}$ In any case, the various classes in a society, albeit apparently defined by their wealth, may in fact be defined by their virtue.

If a regime allows its populace to exercise their varying degrees of acquisitiveness while nonetheless encouraging them to be moderate and generous, the following should result. Those of middling acquisitiveness will have a sufficient amount of property and will be willing to share it; those more acquisitive will, by way of their striving, provide revenue for the city; ${ }^{69}$ those who are least ac-

other regimes, its primary advantage is to keep the people too busy for politics; they will happily elect - on the basis of wealth or capability - a few among them to rule (Pol 1318b9-1319a4). Encouraging farming is, then, a way to turn democracy into oligarchy or aristocracy.

68 By way of a story about Thales of Miletus, Aristotle conveys the power of intellectual activity to supplant the desire to accumulate and consume: Thales figured out a way to make money easily and quickly, "thus showing how easy it is for philosophers to become wealthy if they so wish"; yet Thales was not rich, because, as he explained to those who reproached him for being poor, wealth is not what philosophers "are serious about" (Pol 1259a6-18). See also Shulsky, "Infrastructure," 181.

69 One might also observe that the tension between an individual's desire to increase personal wealth and the good of the whole, "whatever political difficulties it might cause, has the advantage of keeping the ethical question concerning wealth in view; a reconciliation would run the risk of allowing that question to fade from view in so far as the individual's actions no longer raised political resistance against them" (Shulsky, "Infrastructure," 217). 
quisitive will benefit from the voluntarism of the well-off. At least with respect to political stability, it is fortunate if those of middling wealth predominate (Pol IV.11-12). A regime can, however, achieve an overall middling amount of wealth, and thus stability, with a mixture of classes (Pol 1297a6-7). In any case, a regime's economy should be arranged so as to profit from the different natures of its populace (Pol 1296b10-12). ${ }^{70}$

\section{ON THE RELATION BETWEEN POLITICS AND ECONOMICS}

How might Aristotle's teaching on economics be summarizedfor a legislator, for example? First, only at the peril of their regime can legislators adopt the strategy of solving economic matters by addressing exclusively the moral constitution or relationships of their populace. The urgency and universality of neediness eventually impacts on such a regime either through starvation or insurrection or both; the "naturally private" will not let itself be ignored. ${ }^{71}$ Furthermore, an exclusively educational approach to economic problems overlooks the fact that in a naturally ordered regime those who affect the economy the most have the least capacity for virtue. At best, they are likely to think in terms of what is good for the economy, not in terms of what is good for the whole; charity and moderation may be lost sight of. Thus, Aristotle concludes, the fundamental macroeconomic decisions should be made

70 As Ross explains Aristotle's proposed economy, "it is the sort of arrangement under which rich men give to the public the freest admission that is practicable to their picture-galleries, their parks, and their moors. In so far as socialism means a better organisation of industry by the state, Aristotle would be in sympathy with it, for he has a far more positive view of the state's functions than the laissez-faire school of individualism. But in so far as it means the taking away from private industry of its rewards, the attempt to create an equality of possessions which the natural inequality of capacity and industry will constantly upset, he is an individualist, and no one has better expressed the common sense of individualism" (Aristotle, 238). But Ross's surrounding commentary describes rich men out of existence by denying men the means to get rich in Aristotle's regime.

71 Strauss uses this phrase to refer to the body (City and Man, 32). According to Strauss, Aristotle maintains that the public safety or the mere preservation of society should be the highest law only in extreme situations - situations "in which the very existence or independence of society is at stake." At the same time, he admits that "it is not possible . . . to define precisely what constitutes an extreme situation in contradistinction to a normal situation" (Natural Right and History, 160-61). 
by legislators. Education can address economic concerns most effectively if it takes the form of law. In short, an economy is, albeit indirectly, a function of the virtue of a regime's legislators. ${ }^{72}$

Legislators should not, at the other extreme, address economic matters exclusively, or mistake economic prosperity for political success. A populace continually engaged in commerce, trade, and war with a view to empire-preoccupied with acquiring-cannot be happy either individually or collectively. Thus, according to Aristotle, legislators must acknowledge that economic matters are also always moral or political ones. ${ }^{73}$

Not all political matters are economic, for the demands of distributive and commutative justice only partially meet those of political friendship. ${ }^{74}$ But, on the plane of economics, there is a dialectic

72 This returns us to the question, raised earlier in the discussion about Castoriadis's views, as to what Aristotle means by the naturalness of the city. Like Castoriadis, David Keyt maintains that "Aristotle's own principles" in effect show that "the political community is an artifact of the practical reason, not a product of nature"; "Three Fundamental Theorems in Aristotle's Politics," Phronesis 32, no. 1 (1987), 54; see also 59-60. The context of this chapter calls for the following brief response to Keyt. According to Aristotle, although the existence of the economy, like that of the city, is dependent on law, it is a product of nature, for human appetites are its internal source of motion, the presence of which, Keyt argues, defines natural existence according to Aristotle. Consider also Randall's explanation of $\mathrm{Ph}$ 199a11-15, which is consistent with my point and worth quoting at length (one may find it helpful to substitute "economy" where Randall writes "house"): "'Processes by nature' and 'processes by art' . . . are not two quite different kinds of process. 'By nature,' physei, a tree is made out of a seed; 'by art,' apo technēs, a man makes a house out of wood and bricks. 'But,' says Aristotle, 'if a house had been a thing made by nature' - if the wood and bricks had grown into a house - 'it would have been made by nature in the same way as it is now made by art; and if the things made by nature were made also by art'-if men could make a tree- 'they would come to be in the same way as they now do by nature.' There is in each case a necessary order of means and ends that would have to be followed. Both are processes whereby natural materials are made by a natural agent to realize the forms potential in those materials, made to realize their implicit ends. And while nature cannot make a house in any other way than houses are made, and hence must work through man as her agent in housebuilding . . . and while man cannot make a tree, and hence must leave the making of trees to nature, we do not have here two radically incompatible kinds of process, but rather a natural cooperation" (Aristotle, 274-75). On the natural/conventional nature of Aristotle's economy, see also Mansfield, "Marx on Aristotle," 357.

73 See Cropsey, "Political Science and Economics," 39; Mansfield, "Marx on Aristotle," 357-58, 363, 366-67.

${ }^{74}$ By contrast, according to Arendt (whose own views derive from her interpretation of the Greeks), economics is "the enemy of politics" because it lacks the "openendedness" of politics and "rarely produces great speech"; see George Kateb, Hannah Arendt: Politics, Conscience, Evil (Totowa, N.J.: Rowman \& Allanheld, 1983), 117, 122. 
at work between it and the political. The economic arrangements of a regime necessarily shape the moral virtues of the inhabitants: what, where, and how often they produce, acquire, and consume affects their potential for happiness. But so also does their moral constitution, as shaped by their education or training, bear on the economy; only the vantage point of the more human activities reveals the never wholly satisfying nature of the life process and its proper role in life.

On the level of practice, Aristotle's advocacy of the hegemony of the political aims to prevent what amounts to a perverted preoccupation with self-preservation from dominating the lives of citizens and rulers. Such domination would, as Aristotle seems to have foreseen, transform citizens into jobholders and rulers into managers. ${ }^{75}$ Focused on the naturally private, no one would have the time or the inspiration to pursue or to encourage truly private activities.

On the philosophical level, Aristotle shows that the economic does not permeate human relationships. His strategy is to reveal the economic as a practically distinct part of life and a theoretically distinct part of political thinking. His recommendation that regimes physically contain the market may even be understood as a metaphor for his theoretical objective. Aristotle exposes economics ultimately in order to point out that the study that derives from preoccupation with the naturally private is only a part of the study of the public and the private.

75 See Oakeshott, On Human Conduct, 143-47; Arendt, Human Condition, 45. 